Tjalling C. Koopmans Research Institute Tplligh Aoopmanes

Discussion Paper Series nr: 09-03

\title{
The causal effect of institutional quality on outsourcing
}

Hein Roelfsema

Yi Zhang 


\section{Tjalling C. Koopmans Research Institute Utrecht School of Economics \\ Utrecht University}

Janskerkhof 12

3512 BL Utrecht

The Netherlands

telephone $\quad+31302539800$

fax $\quad+31302537373$

website www.koopmansinstitute.uu.nl

The Tjalling C. Koopmans Institute is the research institute and research school of Utrecht School of Economics.

It was founded in 2003, and named after Professor Tjalling C. Koopmans, Dutch-born Nobel Prize laureate in economics of 1975.

In the discussion papers series the Koopmans Institute publishes results of ongoing research for early dissemination of research results, and to enhance discussion with colleagues.

Please send any comments and suggestions on the Koopmans institute, or this series to J.M.vanDort@uu.nl

ontwerp voorblad: WRIK Utrecht

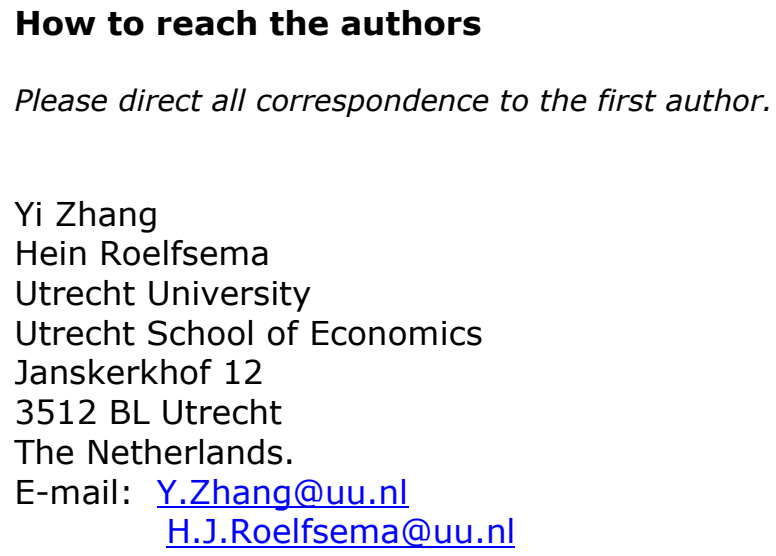


Utrecht School of Economics

Tjalling C. Koopmans Research Institute

Discussion Paper Series 09-03

\title{
The causal effect of institutional quality on outsourcing
}

\author{
Hein Roelfsema \\ Yi Zhang
}

Utrecht School of Economics Utrecht University

February 2009

\begin{abstract}
This paper empirically investigates the relationship between institutional quality and outsourcing to developing economies. In contrast to cross-sectional studies on institutions, this paper uses panel data for 76 countries over 25 years (1980-2004). Employing panel data helps to show the causal relationship by controlling for the fixed effects and dynamic factors. Using within and IV estimations, we find that there is a positive effect of institutional quality on outsourcing in the lower-middle income countries. The quality of institutions is not an important determinant of outsourcing to either low or high income countries.
\end{abstract}

Keywords: Institutional quality, Outsourcing, Developing countries

JEL classification: F15, F23, O19, K11, K12 


\section{Introduction}

In recent years, outsourcing and vertical specialization have become important features of international trade among countries. Currently, as estimated by Yeats (2001), trade in intermediate products takes a share of 30 percent of the world trade in manufactures. Hummels, Ishii and Yi (2001) show that one-third of world export growth is related to trade in vertical specialization. According to International Data Corporation (IDC), the top 100 European outsourcing deals reached 40.5 billion US dollars in 2005. Among Fortune 1000 firms, the number of those involved in offshore outsourcing is more than 95 percent (Offshore research outsourcing, 2005). Additionally, Forrester Research also claims that at least 3.5 million jobs in US and 1.2 million in Europe will be relocated to developing nations by 2015 .

Clearly, the process of vertical specialization is driven by technology shocks. Changes in production technique, such as an increase in the number of production stages, have made fragmentation of production across different countries much easier. In addition, high-tech methods like computer networks have improved the communication between units of production and have made it cheaper for firms to efficiently transfer various stages of the value chain to countries with lower labor costs.

This paper focuses on another often cited rationale for the rise in international outsourcing, namely institutions. Many authors point out that improved quality of institutions (property rights, the rule of law) in many developing countries has reduced the uncertainty of shifting production. For example, offshore outsourcing often requires an investment by a producer in a developing country to produce an input for a downstream firm in a developed nation. Since the value of the outside option is low when the input is firm specific, the revenues to the upstream firm depend on the contract enforcement. Hence, low contract enforcement creates a holdup problem in such relationship-specific transactions, which results in underinvestment. When the parties cannot overcome this hold-up, there will be too little outsourcing given the levels of wages and technological development. 
The crucial role of institutional quality in outsourcing activities raises the question what good institutions are. North (1990) famously states that institutions ${ }^{1}$ act as the constraints designed by humans to shape human interaction. More specifically, La porta et al. (1999) define good institutions as a legal system that can protect property rights and enforce contracts, an uncorrupted bureaucracy, and limited government. Hence, to attract FDI and outsourcing contracts, many developing countries, have been working hard to improve their institutional quality since the beginning of 1990's. Based on World Bank Governance Matters 2006, over the past decade one in six countries had a significant improvement in at least one of the dimensions of government. Over a dozen non-OECD, non-rich, developing countries, including, for example, Slovenia, Chile, Botswana, and Estonia, in fact have higher performance in control of corruption and rule of law than some developed nations, like Greece and Italy.

Given many theoretical papers on the relation between institutional quality and outsourcing, in empirical research, the impact of institutional quality on outsourcing is rarely explored. There are at least two reasons for this. First, outsourcing is relatively difficult to measure, as it is hard to distinguish the part of outsourcing in trade flows. This problem is especially hard to solve when outsourcing time series are requested in dynamic settings. Second, institutional variables may be endogenous because of reversal causality. When outsourcing is important in a country's international trade, this country may keen to build good institutions which are supposed to help attracting outsourcing.

This paper's aim is to overcome these two problems and to show the causal effect of institutional quality on the level of outsourcing. We start with constructing a new proxy to measure outsourcing based on industry trade statistics, a contract intensity indicator $(C I I)$, and the Herfindahl intermediate inputs index $(H I I)$, all discussed in detail in section 3. Then we employ the within and random effects estimation, and apply IV methodology to deal with the endogeneity of the lagged dependent variable and institutional variables. Estimation results show that the quality of institutions has

\footnotetext{
${ }^{1}$ Political theories of institutions (Ertman 1997; Kamen 1997) argue that institutions are used to control assets, and to determine who is in power. The economic and cultural theories of institutions focus on the economic and social factors (Demsetz 1967; Putnam 1993; Landes 1998).
} 
a significantly positive effect on outsourcing engagement only in the lower-middle income countries. For both the low and high income (upper-middle income and high income) countries, institutional quality is not closely related to outsourcing. We will provide our reading of these results in section 4 .

The rest of this paper is organized as follows. We review the related literature in Section 2. We discuss methodology employed, measurement for variables, and model in Section 3. Section 4 shows the estimation results and provides robustness checks. Section 5 concludes.

\section{Related literature}

This paper is closely related to the literature on the organization and geographic choice of multinationals. We first show the theoretical papers that exploit the determinants of outsourcing, and then list some empirical studies that test the effects of institutional quality.

\subsection{Theoretical literature}

Transaction costs economics (Williamson 1975) and imperfect contract theories (Grossman and Hart 1986; Hart and Moore 1990) help to explain how institutional quality can alleviate the hold-up problem. Focusing on the ex post opportunism, Williamson (1975) builds up a theory of contracts under conditions of uncertainty and asymmetric information. He argues that legal enforcement and self enforcement are important to effectively protect the parties against opportunism of their partners. Grossman and Hart (1986) set up a model to explain who should be the owner of the residual decision right of a contractual relation between a supplier and a buyer. They show that the owners of a private property right rely on legal compulsion to prove their ownership before a court.

However, alternative theories on what explains outsourcing point out the importance of the market thickness (Grossman and Helpman 2002; Mclaren, 2000) and the international differences in relative prices (Feenstra and Hanson 1996; Kohler 2003). 
Outsourcing is fenced to the matching problem of finding suitable partners. Since free trade enlarges the inputs markets, increased openness can help firms to find more potential partners. Low labor costs in developing economies are supposed to attract more firms to use outsourcing strategy. We combine these arguments into our paper by controlling for the trade policy and wages rates.

\subsection{Empirical studies}

By now there are many empirical papers on the effects of institutional quality on economic outcomes in general. Many believe that countries with better institutions perform better in international economic activities. For example, Anderson and Marcouiller (2002), Berkowitz et al. (2004), and Ranjan and Lee (2004) all find that a country's volume of trade increases with the quality of institutions. Nordas (2004) shows that an economy engages more in the vertical specialization if it controls corruption. Globerman and Shapiro (2002) argue that the national political infrastructure of a country helps to build a favourable environment for investment and therefore matters to attract FDI. Furthermore, Rossi and Volpin (2001) show that M\&A is proved to be closely related to the laws and regulations of a country. They argue that institutional quality defines the performance of the financial market and therefore is important for M\&A activities.

Levchenko (2004) and Nunn (2005) are closely related to this paper in ways of specifying industries which rely on institutions. By adding the institutional intensity to an empirical model of Romails (2004), Levchenko (2004) tests the impact of institutions on countries' competitive advantages using import data for the US. He uses the Herfindahl intermediate inputs index to measure the product complexity and institutional dependence. He concludes that countries with better institutions export more in industries which rely relatively heavily on institutions. Nunn (2005) identifies the relationship between institutions and certain sectors by constructing a contract intensity index (Rauch, 1999). Products are viewed as relationship-specific if they are not likely and difficult to resell in the market. In a cross section framework, Nunn finds that institutions have a positive impact on the competitive advantage in products which are contract-intensive. This finding and the approach of measuring the institutional dependence help us to build the outsourcing proxy in this paper. 


\section{Data and Methodology}

To identify the causal impact of institutional quality, instrumental variables have been used to control for endogenous variables of institutions. Given variables closely correlated with institutional quality and not affected by outsourcing, we are able to present causality. Widely used instruments for institutional quality are legal origin and latitude (Levchenko 2004; Nunn 2005). However, we need a more complicated methodology in our paper, because we have to consider the dynamic path of outsourcing. It is very likely that partnership between the input producer and the downstream firm may last for a long period. Therefore, outsourcing last year affects outsourcing this year. In dynamic settings, reversal causality is not the only difficulty in finding causal impact of institutional quality on outsourcing, because outsourcing last year also affects institutional quality this year. If we omit the dynamic factor, it is very likely that we overestimate the effect of institutional quality. Meanwhile, in dynamic models variables constant over time such as legal origin are not sufficient to instrument dynamic institutional quality. In this case internal instruments are candidates to instrument current institutional quality.

\subsection{Methodology}

Following the standard panel estimation procedures, we start with testing the panel unit roots and panel cointegration of the series ${ }^{2}$. In our sample of 25 years "Nickell bias" is negligible since the bias is of order of $1 / T$ (Judsen and Owen 1999). This argument can be proved by similar results of the fixed effects estimation and dynamic IV estimation in Table 5. Therefore, using dynamic fixed effects estimation we investigate the impact of institutions on outsourcing to countries with different income levels. Then we explore the nonlinear and long-run impact of institutional quality on outsourcing.

\footnotetext{
2 Because all the panel unit roots and cointegration tests in STATA are not applicable for the unbalanced panel, we run the tests based on a selected balanced sub-panel which covers 55 countries out of 76 in the whole sample.
} 
Since the endogenous institutional variable may cause biased and inconsistent results, we employ dynamic panel IV estimation (Anderson and Hsiao 1981) and use internal instruments for institutional and the lagged dependent variables. Under the assumptions that the explanatory variables are weakly exogenous (i.e., the explanatory variables are not correlated with future realizations of the error term), and that there is no serial correlation in the error term, lagged variables are valid to instrument the current levels. Finally, we perform a range of robustness checks.

To test the impact of the institutional quality on outsourcing in developing countries, we need to measure three groups of variables, which are outsourcing, the quality of institutions, and other controls. We present these variables below. The sample chosen covers 76 developing countries over 25 years from 1980 to 2004.

\subsection{The measurement for outsourcing}

To conduct causality analysis, our methodology requests a measurement for outsourcing which differs across country and varies over time. In offshore outsourcing partnerships, upstream firms in developing countries have contracts with downstream firms in developed countries and then export inputs to these foreign partners. However, it is difficult to obtain data on the share of outsourcing exports in total exports, because in many countries there are no specific statistics on outsourcing. In this paper, we propose a way of building an outsourcing proxy based on a contract intensity indicator $(C I I)$ and the Herfindahl intermediate inputs index (HII).

First, there is more outsourcing or vertical investment in industries that need more relationship-specific inputs in the process of production. Borrowing from Rauch (1999) and Nunn (2005), we use the contract intensity Indicator (CII) to measure the extent of the relationship-specific investment in production. As in Nunn (2005), we assume that if an input is neither traded on an organized exchange nor is reference priced, this input is relationship-specific. In this case, the hold-up problem is severe because it is hard for suppliers to resell the inputs when the buyers break the contracts. Based on the expression of $C I I$ below, the value of the contract intensity index for a final product is higher if more relationship-specific inputs are used. 
$C I I_{j}=\sum \theta_{h j} R_{h}$,

where $\theta_{h j}$ is the value of input $h$ used to produce one unit of final goods in industry $j$, and $R_{h}$ is the proportion of input $h$ that is neither sold on an organized exchange nor reference priced.

In sectors with high $C I I$, firms are hard to buy inputs required in the open market. Hence, there are more outsourcing contracts or verticalFDI in these sectors. The main difference between this paper and Nunn (2005) is that he focuses on the industry level competitive advantage across countries in a certain year, while this paper creates an aggregate time-varying outsourcing index for countries and shows the dynamic outsourcing changes.

In addition, we assume that there are more outsourcing activities rather than vertical investments in industries which have more complex final products. Firms tend to outsource rather than establish a new factory for one input if the final product involves many intermediate inputs. Therefore, we try to use the Herfindahl intermediate inputs index $(H I I)$, which measures the concentration of inputs by industry, to obtain a more precise outsourcing proxy. The Herfindahl index is defined as the sum of the squares of the shares of each input for producing one unit final goods. Therefore, the final goods in one industry are more complicated if this index is smaller. Then, in a sector that has both higher CII and lower HII (more complex), firms in developed countries are more likely to outsource.

Rauch (1999) has both liberal and conservative estimates. We employ the conservative estimate as the main tool. Also there may be reference prices for the goods not sold on an exchange, which can be viewed as an intermediate level of relationship-specificity. More estimates are applied to robustness checks. Rauch's original classification groups goods by the 4-digit SITC Rev. 2 system. We convert this to the 3-digit ISIC Rev. 2 system in consistent with Input-Output tables. Under this scheme 28 sectors are involved in our paper and listed in Table 1. Figures 1 and 2 present the distribution patterns of contract intensity and inputs concentration among sectors. 
Table 1: International Standard Industrial Classification, 3-digit level of Revision 2

\begin{tabular}{|c|c|c|c|}
\hline Code & Industry & Code & Industry \\
\hline 311 & Food products & 354 & $\begin{array}{l}\text { Miscellaneous petroleum and coal } \\
\text { products }\end{array}$ \\
\hline 313 & Beverages & 355 & Rubber products \\
\hline 314 & Tobacco & 356 & Plastic products \\
\hline 321 & Textiles & 361 & Pottery, china, earthenware \\
\hline 322 & $\begin{array}{l}\text { Wearing apparel, except } \\
\text { footwear }\end{array}$ & 362 & Glass and products \\
\hline 323 & Leather products & 369 & $\begin{array}{l}\text { Other non- metallic mineral } \\
\text { products }\end{array}$ \\
\hline 324 & $\begin{array}{l}\text { Footwear, except rubber or } \\
\text { plastic }\end{array}$ & 371 & Iron and steel \\
\hline 331 & Wood products, except furniture & 372 & Non-ferrous metals \\
\hline 332 & Furniture, except metal & 381 & Fabricated metal products \\
\hline 341 & Paper and products & 382 & Machinery, except electrical \\
\hline 342 & Printing and publishing & 383 & Machinery, electric \\
\hline 351 & Industrial chemicals & 384 & Transport equipment \\
\hline 352 & Other chemicals & 385 & $\begin{array}{l}\text { Professional and scientific } \\
\text { equipment }\end{array}$ \\
\hline 353 & Petroleum refineries & 390 & Other manufactured products \\
\hline
\end{tabular}

\section{Sectors ranked by contract intensity index}

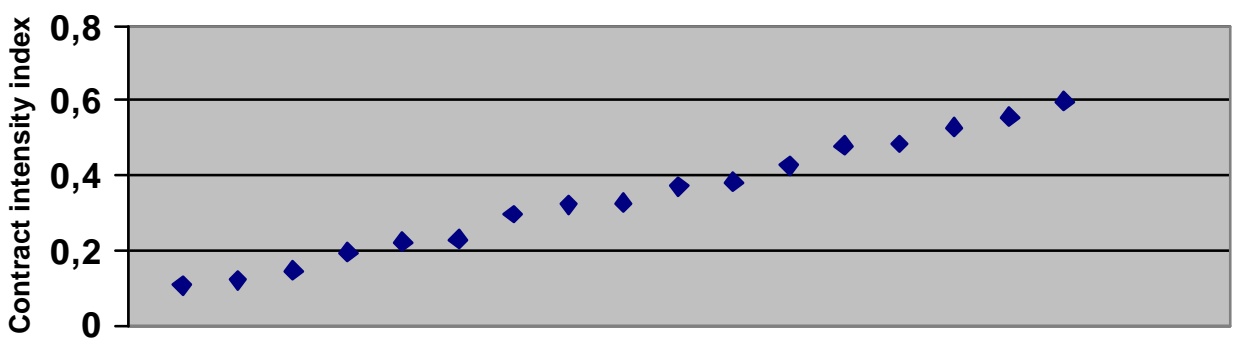

Industry

From left to right: industry $372,311 / 312,371,353 / 354,313 / 314,341 / 342$, 351/352/355/359, 361/362/369, 381, 390, 331/332, 321,382, 323, 383/385, 322, 384

Figure 1 


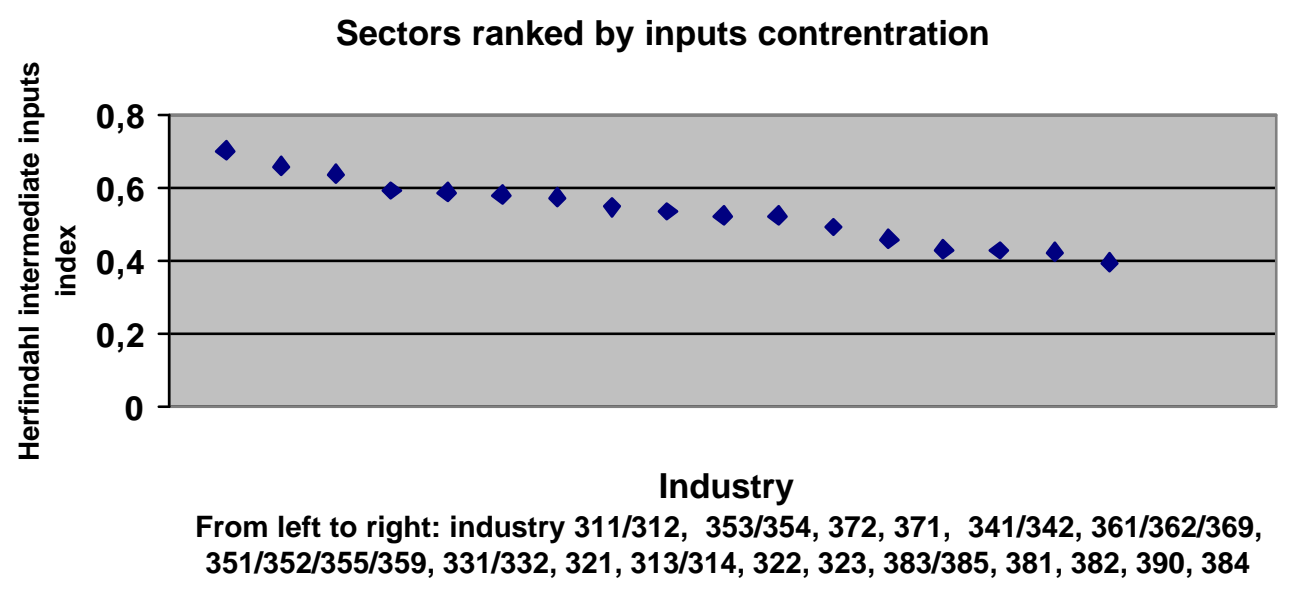

Figure 2

Relying on the arguments above, we construct the outsourcing proxy following three steps. (Assume economy $i$, industry $j$ and year $t$.) First, we calculate $C I I$ and HII for each industry in 20 developed countries based on their Input-Output tables ${ }^{3}$. These indicators are constant over time but different among countries. Second, we take the mean of $C I I$ and $H I I$ for each industry which are $C I I_{j}$ and $H I I_{j}$. Then we use these averaged $^{4}$ data to show the index of outsourcing probability in a certain industry ${ }^{5}$. Sectors are ranked by their probability of outsourcing in Figure 3.

$I N P R O U T S_{j}=\frac{C I I_{j}}{H I_{j}}$

\footnotetext{
${ }^{3}$ We assume developing countries to be the outsourcing destinations. These two indicators reflect industry nature by looking at the intermediate inputs used. It is the firms in developed countries that produce the final goods and therefore determine the industry characteristic related to outsourcing. Input-Output tables used are based on the Global Trade Analysis Project (GTAP) database version. The GTAP database uses data from the early ' 90 s in constructing its input and output tables. For more information, refer to www.gtap.org. Developed countries in this paper include Australia, Austria, Canada, Cyprus, Denmark, Finland, France, Germany, Greece, Ireland, Italy, Japan, the Netherlands, Norway, New Zealand, Portugal, Spain, Switzerland, UK, and USA. The limitation of using these I-O tables in this paper is to apply the production structure in ' 90 s to all the 25 years from 1980 to 2004 in our sample.

${ }^{4}$ The main limitation is that the probability calculated by using the averaged data is constant over time. Given the data available, it is hard to get time-varying data for a large number of countries.

${ }^{5}$ Robustness checks show more methods of constructing this probability such as by averaging these two and by giving different weights to these indexes.
} 


\section{Sectors ranked by probability of outsourcing}

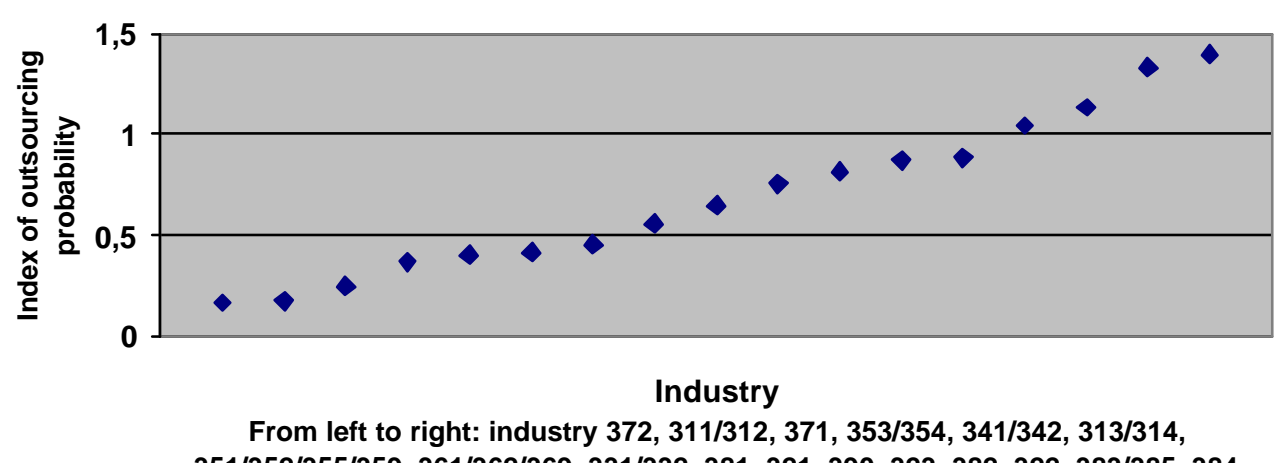

$351 / 352 / 355 / 359,361 / 362 / 369,331 / 332,381,321,390,323,382,322,383 / 385,384$

Figure 3

Third, we calculate the Balassa index ${ }^{6}$ to reflect the relative export performance of developing economies by industry. Export data are taken from UCTAD based on the 3-digit SITC Rev.3 system. We convert the data into the 3-digit ISIC Rev. 2 system to be consistent with other indexes. Using the index on outsourcing probability (INPROUTS) as the weighting factor, we claim that a developing country attracts more outsourcing if it has higher exports performance in outsourcing-likely sectors. Hence, the outsourcing $\operatorname{proxy}^{7}$ of the developing countries is defined as:

OUTS $_{i t}=\frac{\sum_{j} \text { INPROUTS }_{j} \times \text { Balassa }_{i j t}}{\sum_{j} \text { Balassa }_{i j t}}$

\subsection{Institutional quality and controls}

\footnotetext{
${ }^{6}$ Balassa' s (1965) measure of relative export, defined as a country's share of world exports of a good divided by its share of total world exports. The index for country $i$ good $j$ is Balassa $_{i j}=\left(X_{i j} / X_{w j}\right) /\left(X_{i t} / X_{w t}\right)$ where $X_{i j}$ is exports by country $i$ ( $w=$ world) of good $j$ ( $t=$ total for all goods). Though it would be better to use the intermediate inputs exports Balassa index, we apply the total exports data based on the assumption that the overall exports performance can reflect the intermediate inputs exports performance.

7 Strictly speaking, it is more precise to multiply the outsourcing probability of sector $j$ with the relative exports of each industry that provides the input for the final good $j$. The outsourcing proxy here only accounts for the inter-industry intermediate inputs trade, based on the fact that the largest part of inputs used in an industry comes from the same industry.
} 
Variable used to represent institutional quality is an ICRG (International Country Risk Guide) indicator of quality of government $(I C R G)$, which is taken from the PRS Group. This indicator varies from 0 to 1 and is built on "corruption, law and order, and bureaucracy quality". Data for 145 countries from 1984 to $2003^{8}$ are available.

As for control variables, we use GDP per capital (GDPPC) (UNCTAD) as a proxy for wage rates in outsourcing destinations, as in Helpman (1987) and Brainard (1997). Related to the market thickness argument, we choose the openness of a nation (World Bank Development Indicators) to show the trade policy. Road density, airport density, internet using (World Bank Development Indicators 2005), and the freedom of the information markets (Heritage Foundation) are applied to capture the infrastructure situation. Infrastructure in transportation and communication system is quite important for the in-time and high quality delivery of the intermediate inputs, which is a key for the final goods production. Therefore, better infrastructure helps to attract more outsourcing. We take the distance from each developing country to the USA (DISTUSA), its latitude, and region dummy to measure its distance to major markets. Distance to major markets reflects trade costs of outsourcing exports and a negative impact is expected. Because these variables are time-invariant, they are only relevant in random effects estimation. In addition, index on the freedom of FDI (Heritage Foundation) is used to reflect the investment policy. Finally, all regressions control for year dummies and country-specific effects. The summary and correlations of main variables are presented in Table 2 below. Figures 4 to 7 reflect changes of institutional quality and outsourcing over time and differences among income groups.

Based on the model below, we test the effects of the determinant factors of outsourcing. We lay our main interest on the coefficient $\beta$, which represents the influence of institutions on the outsourcing proxy.

OUTS $_{i t}=\alpha+\gamma$ OUTS $_{i t-1}+\beta$ INSTITUTIONS $_{i t}+\lambda$ CONTROL $_{i t}+\delta_{1}$ YEAR $_{t}+\delta_{2} \operatorname{COUNTRY~}_{i}+\varepsilon_{i t}$

\footnotetext{
${ }^{8}$ Because of data availability, we use the values in 2003 to get data for year 2004 and assume that the indicator in 1984 reflects the institutional level from 1980 to 1983.
} 
Table 2.1: Summary and Correlation

\begin{tabular}{l|lllll}
\hline Variable & Obs. & Mean & Std. Dev. & Min & Max \\
\hline OUTS $(\ln )$ & 1541 & 0.9284 & 0.3674 & -0.6162 & 1.6232 \\
ICRG $(\ln )$ & 1541 & -0.8958 & 0.4785 & -2.8904 & -0.1023 \\
GDPPC $(\ln )$ & 1541 & 6.8478 & 1.0668 & 4.5763 & 10.1535 \\
OPENNESS $(\ln )$ & 1541 & 4.0169 & 0.5766 & 2.2101 & 5.8320 \\
LATITUDE & 1541 & 0.1946 & 0.1320 & 0.0111 & 0.6667 \\
REGION & 1541 & 4.1888 & 2.2531 & 2 & 10 \\
DISTUSA $(\ln )$ & 1541 & 8.9512 & 0.5052 & 7.4793 & 9.6915 \\
ROAD $(\ln )$ & 1541 & 1.0625 & 0.6758 & -0.9267 & 3.0161 \\
AIRPORT $(\ln )$ & 1541 & 3.5207 & 2.1061 & -2.3026 & 8.9994 \\
FREEFDI & 1541 & 2.7690 & 0.8678 & 1 & 5 \\
FREEINFOR & 1541 & 3.9319 & 1.0580 & 1 & 5 \\
\hline
\end{tabular}

\begin{tabular}{l|llllll}
\hline Variable & $\begin{array}{l}\text { OUTS } \\
(\ln )\end{array}$ & $\begin{array}{l}\text { ICRG } \\
(\ln )\end{array}$ & $\begin{array}{l}\text { GDPPC } \\
(\ln )\end{array}$ & $\begin{array}{l}\text { OPEN } \\
(\ln )\end{array}$ & LATI & REGI \\
\hline OUTS $(\ln )$ & 1.0000 & & & & & \\
ICRG $(\ln )$ & 0.0102 & 1.0000 & & & & \\
GDPPC $(\ln )$ & -0.1810 & 0.4161 & 1.0000 & & & \\
OPENNESS $(\ln )$ & 0.0330 & 0.1050 & 0.1758 & 1.0000 & & \\
LATITUDE & -0.0440 & 0.1089 & 0.1589 & -0.2236 & 1.0000 & \\
REGION & 0.2441 & -0.0023 & -0.1246 & 0.2442 & -0.1389 & 1.0000 \\
DISTUSA $(\ln )$ & 0.0803 & 0.1205 & -0.2371 & -0.0444 & 0.0554 & 0.3426 \\
ROAD $(\ln )$ & -0.1109 & 0.1244 & 0.3461 & 0.0154 & -0.1159 & -0.0291 \\
AIRPORT $(\ln )$ & 0.0131 & 0.3824 & 0.4324 & -0.1631 & 0.1636 & 0.2085 \\
FREEFDI & 0.0296 & -0.1878 & -0.3700 & -0.0250 & 0.0125 & -0.0210 \\
FREEINFOR & -0.0137 & -0.3608 & -0.4199 & -0.2041 & 0.0776 & -0.0961 \\
\hline
\end{tabular}

\begin{tabular}{l|lllll}
\hline Variable & $\begin{array}{l}\text { DIST } ~ \\
(\ln )\end{array}$ & $\begin{array}{l}\text { ROAD } \\
(\ln )\end{array}$ & $\begin{array}{l}\text { AIRPORT } \\
(\ln )\end{array}$ & FREEFDI & INFOR \\
\hline DISTUSA $(\ln )$ & 1.0000 & & & & \\
ROAD $(\ln )$ & -0.1663 & 1.0000 & & & \\
AIRPORT $(\ln )$ & 0.3468 & -0.0647 & 1.0000 & & \\
FREEFDI & 0.1334 & -0.2842 & -0.1180 & 1.0000 & \\
FREEINFOR & -0.0721 & -0.0044 & -0.2392 & 0.3461 & 1.0000 \\
\hline
\end{tabular}

Table 2.2: Summary of $O U T S$ and ICRG for different income groups

\begin{tabular}{l|lllll}
\hline Low income & Obs. & Mean & Std. Dev. & Min & Max \\
\hline OUTS & 560 & 2.9088 & 0.9353 & 0.5751 & 5.0693 \\
ICRG & 560 & 0.4051 & 0.1548 & 0.0556 & 0.6945 \\
\hline \multicolumn{7}{l}{} \\
\hline Lower-Middle & Obs. & Mean & Std. Dev. & Min & Max \\
\hline OUTS & 643 & 2.5250 & 0.7006 & 0.5992 & 3.8110 \\
ICRG & 643 & 0.4314 & 0.1523 & 0.1111 & 0.7500 \\
\hline \multicolumn{7}{l}{} \\
\hline High income & Obs. & Mean & Std. Dev. & Min & Max \\
\hline OUTS & 338 & 2.5926 & 0.6315 & 0.5400 & 3.8090 \\
ICRG & 338 & 0.5465 & 0.1449 & 0.1111 & 0.9028 \\
\hline
\end{tabular}




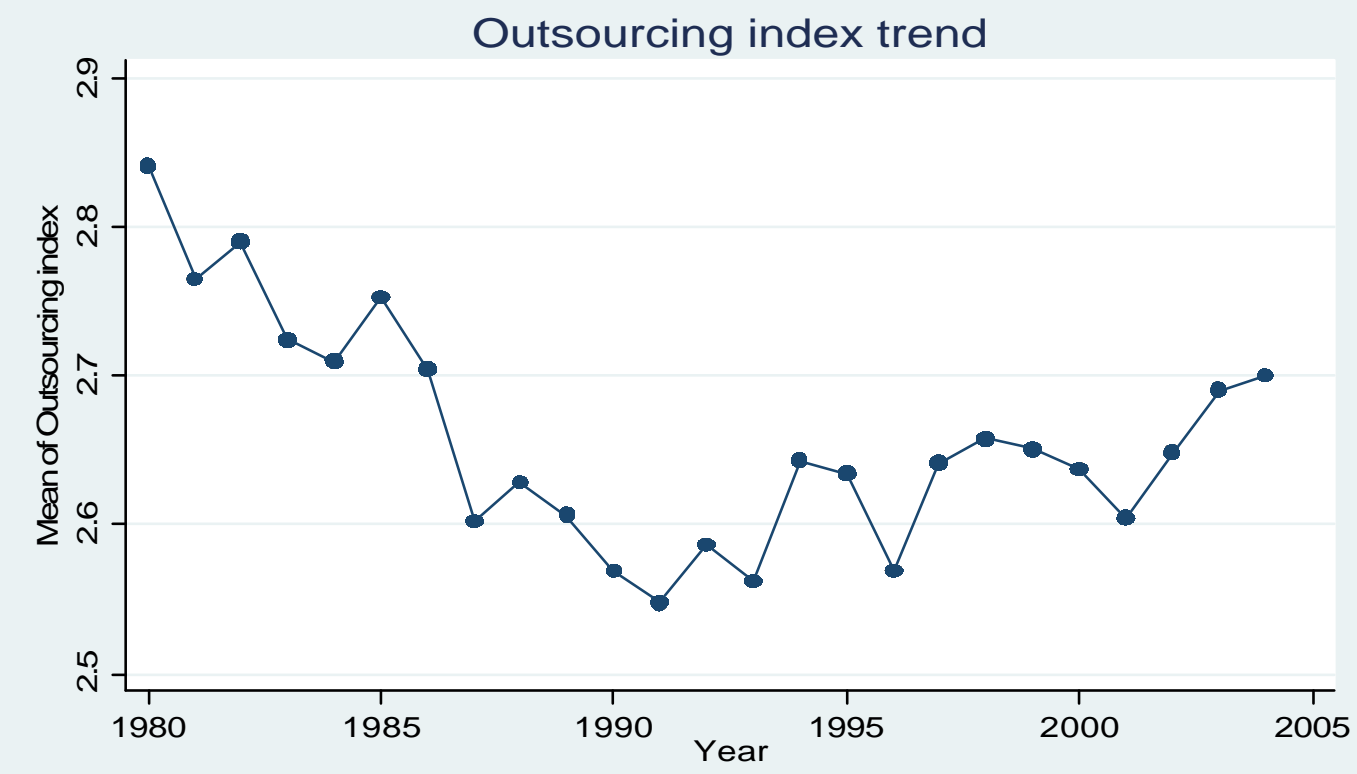

Figure 4

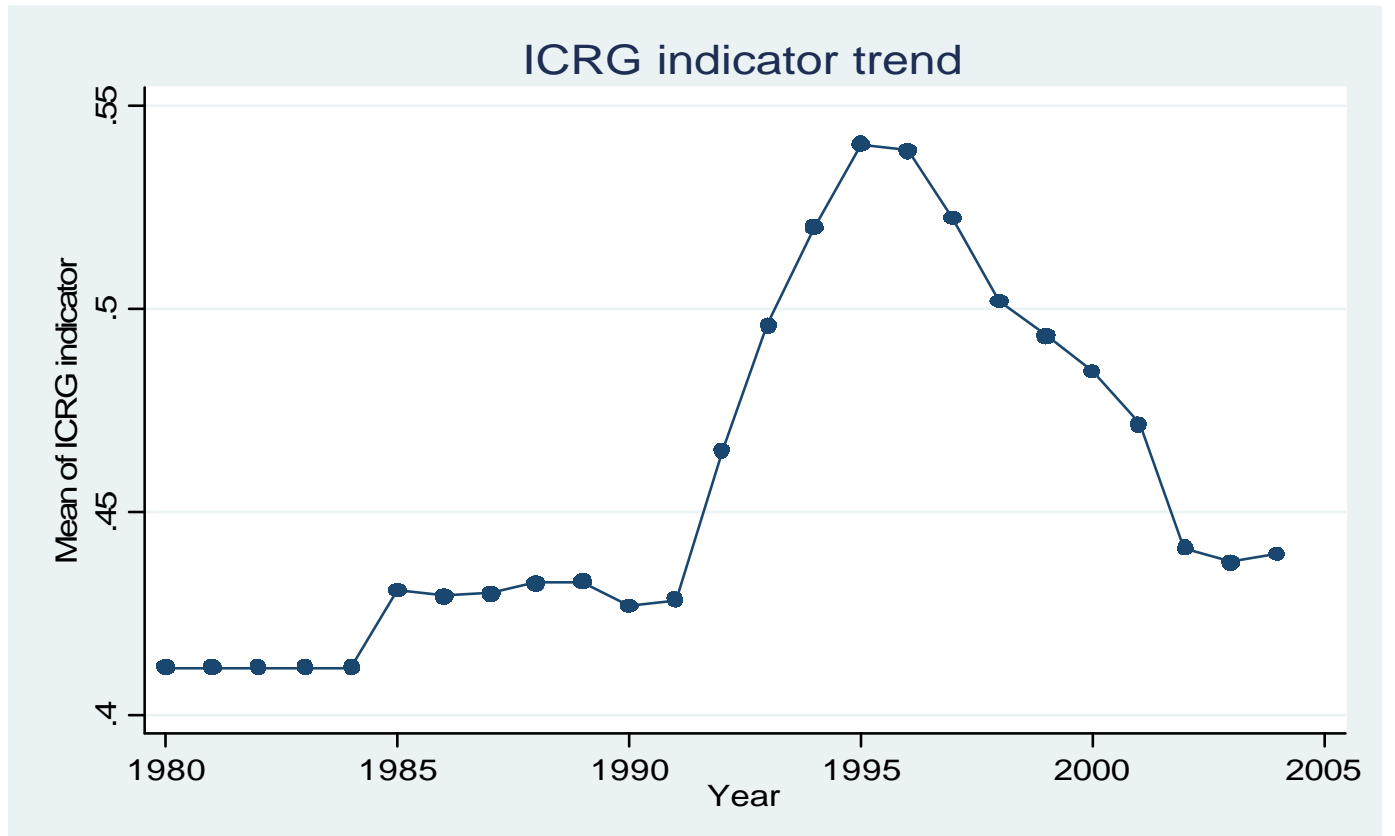

Figure 5 


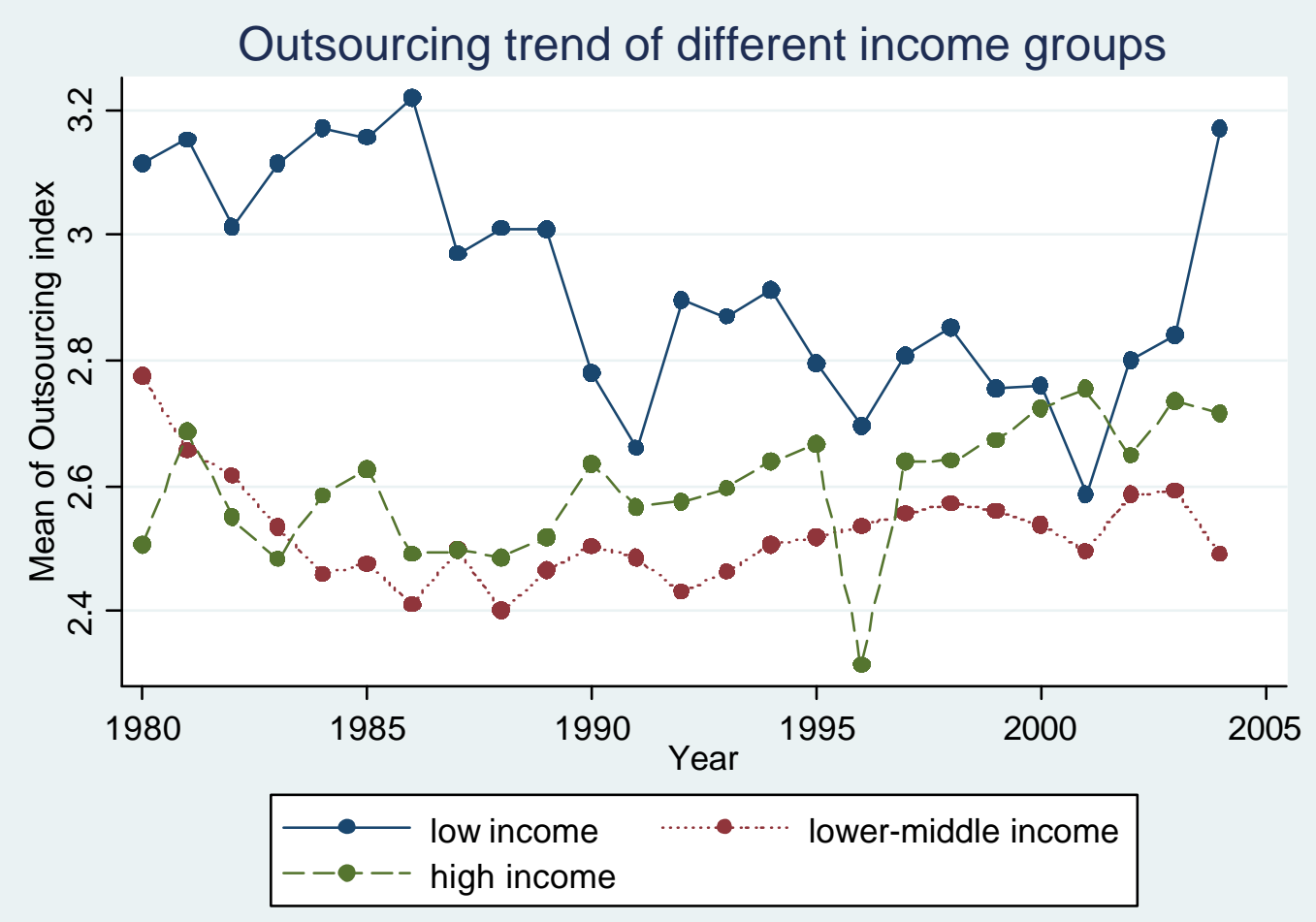

Figure 6

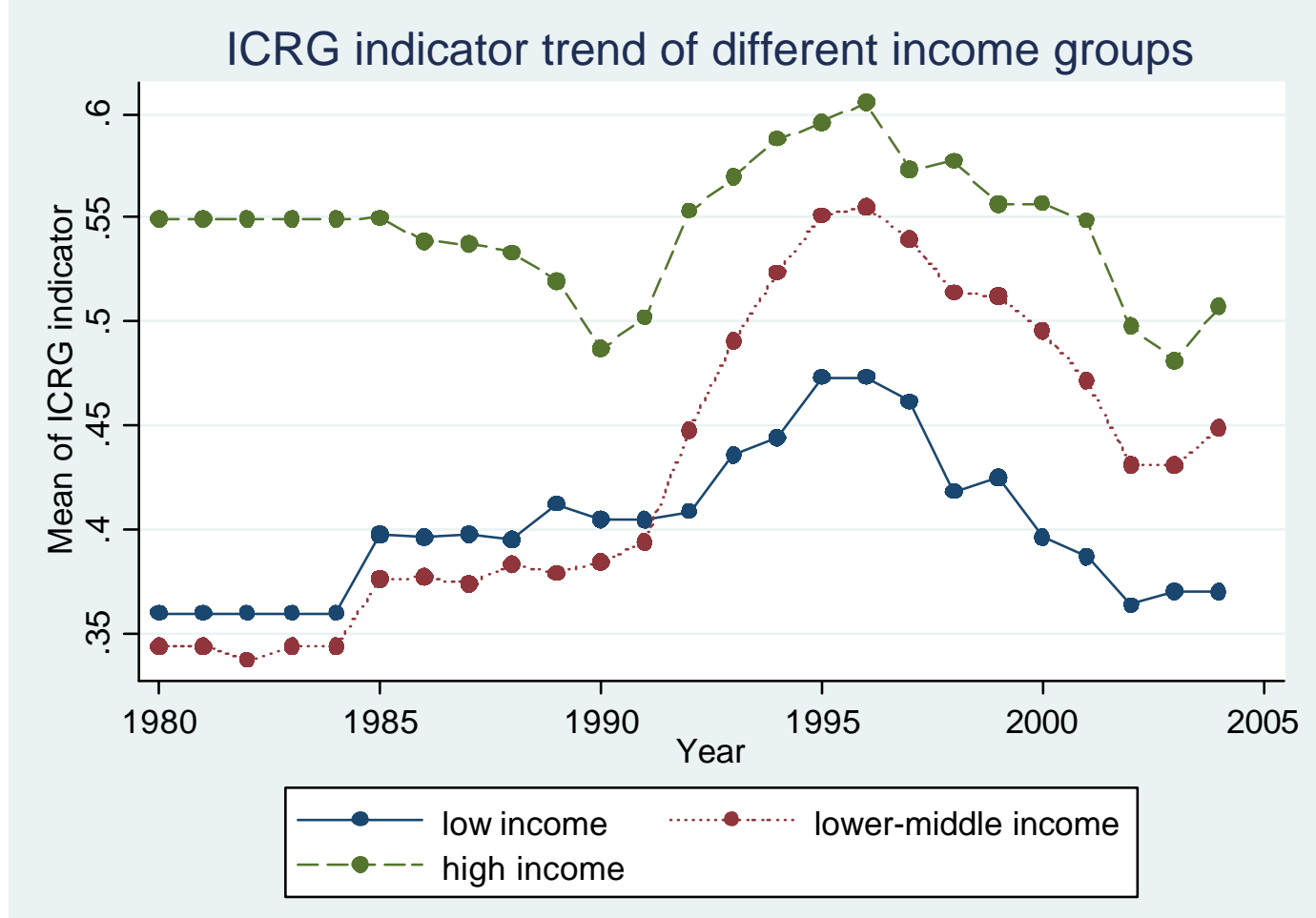

Figure 7 


\section{Results}

Table 3 indicates that series concerned are cointegrated. Therefore, the standard estimation methods and inferences are valid.

Table 3: Panel cointegration tests (for a balanced sub-panel covering 55 countries)

\begin{tabular}{|c|c|c|c|}
\hline Test & & & \\
\hline Levin-Lin-Chu test & p-value: 0.00 & & \\
\hline Im-Pesaran-Shin test & p-value: 0.00 & & \\
\hline Nyblom-Harvey (2000) statistic & $\begin{array}{l}11.46 \\
\text { Critical value: } \mathrm{N}= \\
5 \% \\
1 \%\end{array}$ & $\begin{array}{c}75 \\
5.62 \\
5.91\end{array}$ & $\begin{array}{l}50 \\
3.85 \\
4.09\end{array}$ \\
\hline
\end{tabular}

Note: Null hypothesis: no cointegration. Unit roots tests results are not reported here. Based on three panel unit roots tests (Levin-Lin-Chu test, Im-Pesaran-Shin test, and Hadri panel unit root test), all the series are non-stationary and I (1).

Table 4 displays the fixed effects and random effects estimates based on the specification with the income-grouped institutional variables. Random effects estimation used passes the Hausman Test. Results of applying the whole sample implies that institutional quality has insignificant impact. The possible reason is the mixed effects of institutional quality on outsourcing to countries in different stages of development.

Therefore, we split developing countries into three different income categories by adding income dummies ${ }^{9}$. Tests for joint significance show that the quality of institutions is only important in the lower-middle income economies. In linear specifications, if the ICRG government quality indicator $(I C R G)$ goes up by $1 \%$, the outsourcing index increases by around $0.08 \%$ (static) and $0.04 \%$ (dynamic) respectively. The results show that we overestimate the impact of institutional quality if dynamic factor is omitted. However, in both low and high income countries, there is no clear causal impact of institutions on outsourcing. The possible reason is that

\footnotetext{
${ }^{9}$ Income groups are divided according to 2005 GNI (gross national income) per capita, provided by the World Bank. The groups are: low income, $\$ 875$ or less; lower-middle income, $\$ 876$ to $\$ 3465$; upper middle income, $\$ 3466$ to $\$ 10,725$; high income, $\$ 10,726$ or more. We use the low income group as the base category. LMIDDLE equals one if the country is the lower-middle income countries, zero otherwise; $H I G H$ equals one if the country is the up-middle and high income nations, zero otherwise.
} 
outsourcing firms may choose the low income countries for low labor costs and pay relatively little attention to other factors in these poor economies. Therefore, institutional quality does not matter much in the low income countries. With respect to the high income countries, further improvement of institutions may not yield major change in outsourcing because they tend to have high quality of institutions initially. This explanation is supported by the non-linear relation between institutions and outsourcing. We test the non-linear relationship between these two by adding the quadratic and GDP per capita interacted terms to each group. Within estimates support an inversely U-shaped institutional impact on outsourcing over time. For example, the negative quadratic (-0.007-0.006) and GDP per capita interacted (-0.0360.016) terms in dynamic setting show that institutional quality has a diminishing impact on outsourcing, and that the marginal effect of institutional quality decreases with income. Finally, there is a significant long-run influence of institutions on outsourcing to the lower-middle income group (0.07\%), given the results of the dynamic error correction model in the last column. In addition, among the control variables, GDP per capita and openness are relatively stable and significant, which supports the low costs of production and market thickness theories.

Since the fixed effects estimates may be biased, results of dynamic IV estimations using internal instruments are shown in Table 5. Column (1) provides a baseline of the fixed effects estimation for comparison. Column (2) presents Anderson and Hsiao estimates. The institutional interactions in Column (3) reveal the impact of institutional quality on outsourcing to the low, lower-middle, and high income countries. In this column, the lagged dependent variable is treated as exogenous and the two years lagged institutional variable is the instrument.

Across the panels, the estimates are similar in size and significance level. Similar results for the lagged dependent variable prove that the "Nickell bias" is negligible in our sample. Moreover, both endogeneity tests and the comparison of results show that as long as we control for potentially omitted variable dynamic outsourcing, the ICRG government quality indicator is exogenous. Hence, we are able to identify the causal effect of institutional quality on outsourcing by applying the dynamic fixed effects estimation. 
Table 4: Basic results of the standard panel estimation (Income grouped)

Dependent variable: Outsourcing index OUTS $(\ln )$

\begin{tabular}{|c|c|c|c|c|c|c|c|c|}
\hline & \multicolumn{4}{|c|}{ (1) Static estimation } & \multicolumn{4}{|c|}{ (2) Dynamic estimation } \\
\hline $\begin{array}{l}\text { Independent } \\
\text { Variable }\end{array}$ & $\begin{array}{c}\mathrm{FE} \\
\mathrm{AR}(1)\end{array}$ & $\begin{array}{c}\mathrm{RE} \\
\mathrm{AR}(1)\end{array}$ & $\begin{array}{c}\text { Quadratic } \\
\text { FE } \\
\text { AR (1) } \\
\end{array}$ & $\begin{array}{c}\text { GDPPC } \\
\text { interacted } \\
\text { FE AR (1) }\end{array}$ & $\begin{array}{l}\mathrm{FE} \\
\text { robust }\end{array}$ & $\begin{array}{c}\text { Quadratic } \\
\text { FE } \\
\text { robust }\end{array}$ & $\begin{array}{l}\text { GDPPC } \\
\text { interacted } \\
\text { FE robust }\end{array}$ & $\begin{array}{c}\text { Error } \\
\text { correction } \\
\text { model }\end{array}$ \\
\hline OUTS $_{t-1}$ & & & & & $\begin{array}{l}0.659 * * * \\
{[0.051]}\end{array}$ & $\begin{array}{l}0.658 * * * \\
{[0.051]}\end{array}$ & $\begin{array}{l}0.654 * * * \\
{[0.051]}\end{array}$ & $\begin{array}{l}0.659 * * * \\
{[0.051]}\end{array}$ \\
\hline$I C R G$ & $\begin{array}{l}-0.058 \\
{[0.037]}\end{array}$ & $\begin{array}{l}-0.043 \\
{[0.034]}\end{array}$ & $\begin{array}{l}0.085 \\
{[0.185]}\end{array}$ & $\begin{array}{l}-0.259 \\
{[0.226]}\end{array}$ & $\begin{array}{l}-0.024 \\
{[0.021]}\end{array}$ & $\begin{array}{l}0.017 \\
{[0.113]}\end{array}$ & $\begin{array}{l}0.177 \\
{[0.150]}\end{array}$ & $\begin{array}{l}-0.024 \\
{[0.023]}\end{array}$ \\
\hline ICRGLMIDDLE & $\begin{array}{l}0.138 * * * \\
{[0.051]}\end{array}$ & $\begin{array}{l}0.113 * * \\
{[0.048]}\end{array}$ & $\begin{array}{l}0.010 \\
{[0.291]}\end{array}$ & $\begin{array}{l}0.946 * * * \\
{[0.299]}\end{array}$ & $\begin{array}{l}0.060 * * * \\
{[0.023]}\end{array}$ & $\begin{array}{l}0.103 \\
{[0.184]}\end{array}$ & $\begin{array}{l}0.207 \\
{[0.194]}\end{array}$ & $\begin{array}{l}0.061 * * \\
{[0.025]}\end{array}$ \\
\hline ICRGHIGH & $\begin{array}{l}0.063 \\
{[0.096]}\end{array}$ & $\begin{array}{l}0.038 \\
{[0.082]}\end{array}$ & $\begin{array}{l}-0.317 \\
{[1.017]}\end{array}$ & $\begin{array}{l}0.439 \\
{[0.609]}\end{array}$ & $\begin{array}{l}0.012 \\
{[0.037]}\end{array}$ & $\begin{array}{l}-0.161 \\
{[0.196]}\end{array}$ & $\begin{array}{l}0.046 \\
{[0.238]}\end{array}$ & $\begin{array}{l}0.001 \\
{[0.039]}\end{array}$ \\
\hline$I C R G^{2}$ & & & $\begin{array}{l}-0.022 \\
{[0.029]}\end{array}$ & & & $\begin{array}{l}-0.007 \\
{[0.020]}\end{array}$ & & \\
\hline ICRGLMIDDLE ${ }^{2}$ & & & $\begin{array}{l}0.019 \\
{[0.045]}\end{array}$ & & & $\begin{array}{l}-0.006 \\
{[0.029]}\end{array}$ & & \\
\hline$I^{\prime C R G H I G H}{ }^{2}$ & & & $\begin{array}{l}0.053 \\
{[0.134]}\end{array}$ & & & $\begin{array}{l}0.025 \\
{[0.030]}\end{array}$ & & \\
\hline$I C R G * G D P P C$ & & & & $\begin{array}{l}0.036 \\
{[0.040]}\end{array}$ & & & $\begin{array}{l}-0.036 \\
{[0.028]}\end{array}$ & \\
\hline $\begin{array}{l}\text { ICRGLMIDDLE } \\
{ }^{*} \text { GDPPC }\end{array}$ & & & & $-0.127 * * *$ & & & -0.016 & \\
\hline $\begin{array}{l}\text { ICRGHIGH } \\
{ }^{*} G D P P C\end{array}$ & & & & $\begin{array}{l}{[0.048]} \\
-0.057\end{array}$ & & & $\begin{array}{l}{[0.032]} \\
0.007\end{array}$ & \\
\hline$G D P P C$ & $\begin{array}{l}0.009 \\
{[0.023]}\end{array}$ & $\begin{array}{l}-0.001 \\
{[0.023]}\end{array}$ & $\begin{array}{l}0.006 \\
{[0.024]}\end{array}$ & $\begin{array}{l}{[0.077]} \\
-0.013 \\
{[0.035]}\end{array}$ & $\begin{array}{l}-0.006 \\
{[0.016]}\end{array}$ & $\begin{array}{l}-0.005 \\
{[0.016]}\end{array}$ & $\begin{array}{l}{[0.038]} \\
-0.040 * * \\
{[0.019]}\end{array}$ & $\begin{array}{l}-0.003 \\
{[0.017]}\end{array}$ \\
\hline OPENNESS & $\begin{array}{l}0.095 * * * \\
{[0.030]}\end{array}$ & $\begin{array}{l}0.095 * * * \\
{[0.027]}\end{array}$ & $\begin{array}{l}0.093 * * * \\
{[0.031]}\end{array}$ & $\begin{array}{l}0.098 * * * \\
{[0.030]}\end{array}$ & $\begin{array}{l}0.068 * * * \\
{[0.025]}\end{array}$ & $\begin{array}{l}0.067 * * * \\
{[0.025]}\end{array}$ & $\begin{array}{l}0.067 * * * \\
{[0.025]}\end{array}$ & $\begin{array}{l}0.067 * * * \\
{[0.025]}\end{array}$ \\
\hline $\begin{array}{l}\text { DISTUSA } \\
\text { REGION }\end{array}$ & & $\begin{array}{l}-0.141 * \\
{[0.073]} \\
0.044 * * * \\
{[0.016]}\end{array}$ & & & & & & \\
\hline$F$-test (p-value) & $\begin{array}{l}\text { lower- } \\
\text { middle: } \\
\text { p: } 0.02 \\
\text { High } \\
\text { income: } \\
\text { p: } 0.29\end{array}$ & $\begin{array}{l}\text { lower- } \\
\text { middle: } \\
\text { p: } 0.05 \\
\text { High } \\
\text { income: } \\
\text { p: } 0.46\end{array}$ & $\begin{array}{l}\text { lower- } \\
\text { middle: } \\
\text { p: } 0.09 \\
\text { High } \\
\text { income: } \\
\text { p: } 0.60 \\
\text { Low: } \\
\text { p: } 0.26\end{array}$ & $\begin{array}{l}\text { lower- } \\
\text { middle: } \\
\text { p: } 0.00 \\
\text { High } \\
\text { income: } \\
\text { p: } 0.44 \\
\text { Low: } \\
\text { p: } 0.19\end{array}$ & $\begin{array}{l}\text { lower- } \\
\text { middle: } \\
\text { p: } 0.02 \\
\text { High } \\
\text { income: } \\
\text { p: } 0.48\end{array}$ & $\begin{array}{l}\text { lower- } \\
\text { middle: } \\
\text { p: } 0.07 \\
\text { High: } \\
\text { p: } 0.58 \\
\text { Low: } \\
\text { p: } 0.35\end{array}$ & $\begin{array}{l}\text { lower- } \\
\text { middle: } \\
\text { p: } 0.02 \\
\text { High: } \\
\text { p: } 0.47 \\
\text { Low: } \\
\text { p: } 0.30\end{array}$ & $\begin{array}{l}\text { long-term: } \\
\text { lmiddle:0.02 } \\
\text { high: } 0.50 \\
\text { short-term: } \\
\text { lmiddle: } 0.49 \\
\text { high: } 0.58\end{array}$ \\
\hline Obs. & 1541 & 1541 & 1541 & 1541 & 1480 & 1480 & 1480 & 1479 \\
\hline $\begin{array}{l}\text { Number of } \\
\text { Countries }\end{array}$ & 76 & 76 & 76 & 76 & 76 & 76 & 76 & 76 \\
\hline
\end{tabular}

Note: Robust standard errors in parentheses $* * * \mathrm{p}<0.01, * * \mathrm{p}<0.05, * \mathrm{p}<0.1$. Variables used are in natural logarithm form. Other variables in regression but not reported include: year dummies, latitude, road and airport density, internet used, and the freedom of FDI and information market. For the error correction model, the short-term ICRG variables are not significant and not reported here. AR (1) in static settings means the standard errors are corrected for the first order autocorrelation. 
Table 5: Endogeneity tests

Dependent variable: Outsourcing index OUTS $(\ln )$

\begin{tabular}{|c|c|c|c|c|}
\hline Independent & (1) & (2) & \multicolumn{2}{|c|}{ (3) Income dummy interaction } \\
\hline & $\begin{array}{c}\mathrm{FE} \\
\text { robust }\end{array}$ & $\begin{array}{c}\text { Anderson } \\
\text { Hsiao }\end{array}$ & $\begin{array}{l}\mathrm{FE} \\
\text { robust }\end{array}$ & $\begin{array}{c}\text { XTIV } \\
\left(I C R G_{t-2}\right)\end{array}$ \\
\hline OUTS $_{t-1}$ & $\begin{array}{l}0.667 * * * \\
{[0.051]}\end{array}$ & $\begin{array}{l}0.648 * * \\
{[0.297]}\end{array}$ & $\begin{array}{l}0.659 * * * \\
{[0.051]}\end{array}$ & $\begin{array}{l}0.671 * * * \\
{[0.021]}\end{array}$ \\
\hline$I C R G$ & $\begin{array}{l}0.003 \\
{[0.014]}\end{array}$ & $\begin{array}{l}-0.059 \\
{[0.136]}\end{array}$ & $\begin{array}{l}-0.024 \\
{[0.021]}\end{array}$ & $\begin{array}{l}-0.031 \\
{[0.021]}\end{array}$ \\
\hline ICRGLMIDDLE & & & $\begin{array}{l}0.060 * * * \\
{[0.023]}\end{array}$ & $\begin{array}{l}0.060 * * \\
{[0.030]}\end{array}$ \\
\hline ICRGHIGH & & & $\begin{array}{l}0.012 \\
{[0.037]}\end{array}$ & $\begin{array}{l}0.020 \\
{[0.079]}\end{array}$ \\
\hline$G D P P C$ & $\begin{array}{l}-0.007 \\
{[0.015]}\end{array}$ & $\begin{array}{l}0.016 \\
{[0.034]}\end{array}$ & $\begin{array}{l}-0.006 \\
{[0.016]}\end{array}$ & $\begin{array}{l}-0.016 \\
{[0.017]}\end{array}$ \\
\hline OPENNESS & $\begin{array}{l}0.067 * * * \\
{[0.024]}\end{array}$ & $\begin{array}{l}0.068 \\
{[0.050]}\end{array}$ & $\begin{array}{l}0.068 * * * \\
{[0.025]}\end{array}$ & $\begin{array}{l}0.060 * * * \\
{[0.020]}\end{array}$ \\
\hline Sargan test & & 0.82 & & \\
\hline$A R(2)(p$-value $)$ & & 0.38 & & 0.44 \\
\hline $\begin{array}{l}\text { Endogeneity } \\
\text { ( p-value) }\end{array}$ & & $\begin{array}{l}\text { (Hausman) } \\
0.993\end{array}$ & & $\begin{array}{l}\text { (Davidson-MacKinnon) } \\
0.928\end{array}$ \\
\hline First stage $(p)$ & & 0.00 & & 0.00 \\
\hline $\begin{array}{l}F \text {-test for ICRG } \\
\text { variables }\end{array}$ & & & $\begin{array}{l}\text { lower-middle: } \\
\text { p: } 0.02\end{array}$ & $\begin{array}{l}\text { lower-middle: } \\
\text { p: } 0.05\end{array}$ \\
\hline (p-value) & & & $\begin{array}{l}\text { High income: } \\
\text { p: } 0.48\end{array}$ & $\begin{array}{l}\text { High income: } \\
\text { p: } 0.19\end{array}$ \\
\hline Obs. & 1480 & 1352 & 1480 & 1419 \\
\hline $\begin{array}{l}\text { Number of } \\
\text { Countries }\end{array}$ & 76 & 76 & 76 & 76 \\
\hline
\end{tabular}

Note: Robust standard errors in parentheses $* * * \mathrm{p}<0.01, * * \mathrm{p}<0.05, * \mathrm{p}<0.1$. Variables used are in natural logarithm form. Other variables in regression but not reported include: year dummies, latitude, distance to USA, region dummy, road and airport density, internet used, and the freedom of FDI and information market. Since $\operatorname{lnICRG}$ is negative, for the convenience of interpretation, we take linear transformation to get the positive values in the case of using the quadratic terms. In column (2), the instruments are the lagged two and three year dependent variables.

Then we do various robustness checks. Table 6.1 offers the results of income subsamples. In consistent with the basic findings, the quality of institutions only matters in the lower-middle income countries. Table 6.2 shows the results of using different methods to construct the index of outsourcing probability, and those of employing different standards to define the contract intensive indicator. Column (1) uses the exports in money term (in US dollars in current prices and current exchange rates) instead of Balassa index to get the outsourcing index. Column (2) and (5) offers results of alternative methods of calculating the outsourcing probability. Column (6) 
defines the product is contract intensive if it is not sold on exchange but has a reference price. Column (7) reports the results of using the liberal estimation in Rauch (1999) to classify goods. Estimates are similar to those in Table 4 in size and the significance level. Additionally, the insignificant results in Column (8) (the institutional impact on regular Balassa index) confirm that the quality of institutions is only crucial for relationship-specific transactions.

Table 6.1: Results for income sub-samples

Dependent variable: Outsourcing index OUTS $(\ln )$

\begin{tabular}{|c|c|c|c|c|c|c|c|c|}
\hline & (1) low & (2) high & \multicolumn{6}{|c|}{ (3) lower-middle income } \\
\hline Independent & $\mathrm{FE}$ & $\mathrm{FE}$ & FE & $\mathrm{RE}$ & $\mathrm{FE}$ & Arellano & Quadratic & GDPPC \\
\hline Variable & $\mathrm{AR}(1)$ & $\operatorname{AR}(1)$ & $\mathrm{AR}(1)$ & $\operatorname{AR}(1)$ & robust & and Bond & FE & interacted \\
\hline & & & & & & GMM & $\operatorname{AR}(1)$ & FE AR(1) \\
\hline OUTS $_{t-1}$ & & & & & $0.725 * * *$ & $0.659 * * *$ & & \\
\hline & & & & & {$[0.053]$} & {$[0.038]$} & & \\
\hline ICRG & -0.024 & -0.059 & $0.071 * *$ & $0.069 * *$ & 0.013 & 0.021 & 0.058 & $0.697 * *$ \\
\hline & [0.046] & [0.069] & [0.036] & {$[0.034]$} & [0.017] & [0.020] & [0.114] & {$[0.300]$} \\
\hline$I C R G^{2}$ & & & & & & & $\begin{array}{l}-0.006 \\
{[0.043]}\end{array}$ & \\
\hline$I C R G^{*} G D P P C$ & & & & & & & & $-0.092 * *$ \\
\hline & & & & & & & & {$[0.044]$} \\
\hline$G D P P C$ & -0.024 & $-0.074 * *$ & 0.043 & $0.059 * * *$ & -0.015 & $-0.042 *$ & 0.043 & -0.027 \\
\hline & [0.051] & {$[0.037]$} & {$[0.030]$} & {$[0.031]$} & {$[0.022]$} & {$[0.023]$} & {$[0.030]$} & [0.044] \\
\hline OPENNESS & 0.022 & $0.136^{* *}$ & $0.141 * * *$ & 0.159 & $0.083 * * *$ & $0.081 * * *$ & $0.141 * * *$ & $0.150 * * *$ \\
\hline & [0.056] & {$[0.056]$} & {$[0.040]$} & [0.036] & {$[0.031]$} & {$[0.033]$} & {$[0.040]$} & {$[0.039]$} \\
\hline Sargan test & & & & & & 1.00 & & \\
\hline$A R(2)(p$-value $)$ & & & & & & 0.77 & & \\
\hline$F$-test & & & & & & & $\begin{array}{l}2.04 \\
\mathrm{p} \cdot 013\end{array}$ & $\begin{array}{l}4.30 \\
\mathfrak{p} \cdot 0.01\end{array}$ \\
\hline Obs. & 532 & 317 & 616 & 616 & 617 & 586 & 616 & 616 \\
\hline $\begin{array}{l}\text { Number of } \\
\text { Countries }\end{array}$ & 26 & 15 & 27 & 27 & 27 & 27 & 27 & 27 \\
\hline
\end{tabular}

Note: Robust standard errors in parentheses $* * * \mathrm{p}<0.01, * * \mathrm{p}<0.05, * \mathrm{p}<0.1$

Variables used are in natural logarithm form. Other variables in regression but not reported include: year dummies, latitude, distance to USA, region dummy, road and airport density, internet used, and the freedom of FDI and information market. Since $\operatorname{lnICRG}$ is negative, for the convenience of interpretation, we take linear transformation to get the positive values in the case of using the quadratic term. P-value of the second-order serial correlation test for model with OUTS $_{t-1}$ is 0.20 . 
Table 6.2: Fixed effects estimation results of using different outsourcing proxy

(With the lagged dependent variable)

\begin{tabular}{|c|c|c|c|c|c|c|c|c|}
\hline $\begin{array}{l}\text { Institutional } \\
\text { Variable }\end{array}$ & 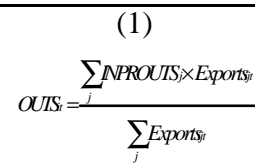 & $\begin{array}{l}(2) \\
\text { INPROUTS } \\
=C I I_{j}\end{array}$ & \begin{tabular}{l}
\multicolumn{1}{c}{$(3)$} \\
$I^{\prime} P R O U T S=$ \\
$C^{\prime} I_{j}-H I I_{j}$
\end{tabular} & $\begin{array}{c}(4) \\
I^{\prime N P R O U T S=} \\
2 C I I_{j}-H I I_{j}\end{array}$ & $\begin{array}{c}(5) \\
I N P R O U T S= \\
C_{1} I_{j}^{*}\left(1-H I I_{j}\right)\end{array}$ & $\begin{array}{c}(6) \\
\text { Reference } \\
\text { priced }\end{array}$ & $\begin{array}{c}(7) \\
\text { Liberal } \\
\text { estimation }\end{array}$ & $\begin{array}{c}(8) \\
\text { Balassa }\end{array}$ \\
\hline$I C R G$ & $\begin{array}{l}-0.025 \\
{[0.018]}\end{array}$ & $\begin{array}{l}0.008 \\
{[0.009]}\end{array}$ & $\begin{array}{l}-0.018 \\
{[0.015]}\end{array}$ & $\begin{array}{l}-0.014 \\
{[0.019]}\end{array}$ & $\begin{array}{l}0.001 \\
{[0.010]}\end{array}$ & $\begin{array}{l}-0.022 \\
{[0.017]}\end{array}$ & $\begin{array}{l}-0.023 \\
{[0.021]}\end{array}$ & $\begin{array}{l}-0.011 \\
{[0.031]}\end{array}$ \\
\hline $\begin{array}{l}\text { ICRGLMID } \\
D L E\end{array}$ & $0.064 * * *$ & 0.013 & $0.055 * * *$ & $0.064 * *$ & $0.023^{*}$ & $0.043 * *$ & $0.059 * * *$ & 0.007 \\
\hline ICRGHIGH & $\begin{array}{l}{[0.021]} \\
-0.014 \\
{[0.034]}\end{array}$ & $\begin{array}{l}{[0.013]} \\
-0.055 * * * \\
{[0.020]}\end{array}$ & $\begin{array}{l}{[0.021]} \\
-0.015 \\
{[0.037]}\end{array}$ & $\begin{array}{l}{[0.028]} \\
-0.040 \\
{[0.046]}\end{array}$ & $\begin{array}{l}{[0.014]} \\
-0.042 * \\
{[0.022]}\end{array}$ & $\begin{array}{l}{[0.018]} \\
0.028 \\
{[0.029]}\end{array}$ & $\begin{array}{l}{[0.023]} \\
0.010 \\
{[0.037]}\end{array}$ & $\begin{array}{l}{[0.037]} \\
0.060 \\
{[0.054]}\end{array}$ \\
\hline $\begin{array}{l}\text {-test } \\
(p \text {-value })\end{array}$ & $\begin{array}{l}\text { lower-middle: } \\
\text { p: } 0.01 \\
\text { High income: } \\
\text { p: } 0.19\end{array}$ & $\begin{array}{l}\text { lower- } \\
\text { middle: } \\
\text { p: } 0.05 \\
\text { High } \\
\text { income: } \\
\text { p: } 0.02 \\
1480\end{array}$ & $\begin{array}{l}\text { lower- } \\
\text { middle: } \\
\text { p: } 0.02 \\
\text { High } \\
\text { income: } \\
\text { p: } 0.37 \\
1480\end{array}$ & $\begin{array}{l}\text { lower- } \\
\text { middle: } \\
\text { p: } 0.04 \\
\text { High } \\
\text { income: } \\
\text { p: } 0.43 \\
1480\end{array}$ & $\begin{array}{l}\text { lower- } \\
\text { middle: } \\
\text { p: } 0.05 \\
\text { High } \\
\text { income: } \\
\text { p: } 0.13 \\
1480\end{array}$ & $\begin{array}{l}\text { lower- } \\
\text { middle: } \\
\text { p: } 0.04 \\
\text { High } \\
\text { income: } \\
\text { p: } 0.40 \\
1480\end{array}$ & $\begin{array}{l}\text { lower- } \\
\text { middle: } \\
\text { p: } 0.02 \\
\text { High } \\
\text { income: } \\
\text { p: } 0.50 \\
1480\end{array}$ & $\begin{array}{l}\text { lower- } \\
\text { middle: } \\
\text { p: } 0.93 \\
\text { High } \\
\text { income: } \\
\text { p: } 0.48 \\
1480\end{array}$ \\
\hline
\end{tabular}

Note: Robust standard errors in parentheses $* * * p<0.01, * * p<0.05, * p<0.1$. For Column (3), we take linear transformation for outsourcing index to get the positive values.

\section{Conclusion}

This paper explains the relationship between institutional quality and outsourcing by employing panel data for 76 developing economies over 25 years (1980 to 2004). Based on the estimation results of panel linear models, we conclude that institutional quality matters for outsourcing to the lower-middle income countries. In these countries, outsourcing relies on better property rights protection and contract enforcement environment. In the low and high income economies, the quality of institutions is not a significant determinant for outsourcing.

Furthermore, there are three points that need more discussion. First, due to data availability, we calculate the contract intensity index and the Herfindahl intermediate inputs index by Input-Output tables in '90s. By applying these indexes to 25 years from 1980 to 2004, we assume that the production structure does not change over more than twenty years. With the evolution of technology, however, production structure has been changed since ' $90 \mathrm{~s}$. The indicators used to get the outsourcing proxy therefore may be not quite appropriate. Updated production tables are needed to solve this problem. Second, the dependent variable in this paper is a proxy for 
outsourcing, since there is no accounting record available on outsourcing in many developing countries. Though based on theoretical assumptions and practical application this proxy works well to show the outsourcing level, further development of accounting may provide more accurate outsourcing statistics. Finally, in this study, we take the wage rates as exogenous for simplicity. However, many studies show that wage rates in both source and target countries can be affected by the change of outsourcing (Grossman and Rossi-Hansberg 2006; Grossman and Helpman 2007). The interaction of factor prices and outsourcing will be explored in the further analyses. 


\section{References}

Acemoglu, D., S. Johnson, and J. Robinson. 2001. Colonial Origins of Comparative Development: An Empirical Investigation. American Economic Review, 91, pp. 13691401.

Acemoglu, D., S. Johnson, and J. Robinson. 2002. Reversal of Fortune: Geography and Institutions in the Making of the Modern World Income Distribution. The Quarterly Journal of Economics, November, pp. 1231-1294.

Acemoglu, D. and S. Johnson. 2004. Unbundling Institutions. Journal of Political Economics, Forthcoming.

Anderson, J. E. and D. Marcouiller. 2002. Insecurity and the Pattern of Trade: An Empirical Investigation. Review of Economics and Statistics, 84, pp. 342-352.

Anderson, T. W. and C. Hsiao. 1981. Estimation of Dynamic Models with Error Components. Journal of the American Statistical Association, 76, pp. 598-606.

Arellano, M. and S. Bond. 1991. Some Tests of Specification for Panel Data: Monte Carlo Evidence and an Application to Employment Equations. Review of Economic Studies, 58, pp. 277-294.

Berkowitz, D., J. Moenius, and K. Pistor. 2004. Trade, Law, and Product Complexity. Mimeo.

Brainard, S.L. (1997). An empirical Assessment of the Proximity-Concentration Trade-off between Multinational Sales and Trade. American Economic Review, 87:4, pp. 520-544.

Demsetz, H. 1967. Toward a Theory of Property Rights. American Economic Review Papers and Proceedings, 57, pp. 347-359.

Djankov, S., R. La Porta, F. Lopez-de-Silanes, and A. Shleifer. 2003. Courts. Quarterly Journal of Economics, 118, pp. 453-517.

Ertman, S. 1997. Birth of the Leviathan. Cambridge: Cambridge University Press.

Feenstra, R. C. and G. H. Hanson. 1996. Foreign Direct Investment, Outsourcing and Relative Wages. In Feenstra, R C., G. M. Grossman, and D. A Irwin, eds. The Political Economy of Trade Policy: Papers in Honour of Jagdish Bhagwati, pp. 89127. Cambridge, Massachusetts: MIT Press.

Globerman, S. and D. Shapiro. 2002. National Political Infrastructure and Foreign Direct Investment. Industry Canada Research Publications Program working paper No. 37.

Grossman, G. M. and E. Helpman. 2007. Fair Wages and Foreign Sourcing. Paper presented at the CEPR conference on Globalization and the Organization of Firms and Markets in Munich Germany, February 10-11, 2007. 
Grossman, G. M. and E. Rossi-Hansberg. 2006. Trading Tasks: A Simple Theory of Offshoring. NBER Working Paper No. W12721.

Grossman, S. J. and O. D. Hart. 1986. The Costs and Benefits of Ownership: A Theory of Vertical and Lateral Integration. Journal of Political Economy, 94, pp. 691719.

Golder, M. 2005. Democratic Electoral Systems around the World. Electoral Studies, 24: pp.103-121.

Gwartney, J. and R. Lawson. 2004. Economic Freedom of World: 2004 Annual Report. Vancouver: The Fraser Institute.

Gwartney, J. and R. Lawson. 2005. Economic Freedom of World: 2005Annual Report. Vancouver: The Fraser Institute.

Hart, O. and J. Moore. 1990. Property-Rights and the Nature of the Firm. Journal of Political Economy, 98:6, pp. 1119-58.

Helpman, E. (1987). Imperfect Competition and International Trade: Evidence from Fourteen Ind ustrial Countries. Journal of the Japanese and International Economies, 1, pp. 62-81.

Helpman E. and G. M. Grossman. 2002. Integration versus outsourcing in industry equilibrium. Quarterly Journal of Economics, 117:1, pp. 85-120.

Hummels, D., J. Ishii, and K. M. Yi. 2001. The nature and growth of vertical specialization in world trade. Journal of International Economics, 54:1, pp. 75-96.

Judsen, R. and A. Owen. 1999. Estimating Dynamic Panel Data Models: A Guide for Macroeconomics. Economic Letters, 65, pp.9-15.

Kamen, H. 1997. The Spanish Inquisition. New Haven: Yale University Press.

Kaufmann, D., A. Kraay, and M. Mastruzzi. 2006. Governance Matters V: Aggregate and Individual Governance Indicators for 1996-2005. The World Bank.

Kohler, W. 2003. Aspects of International Fragmentation. Review of International Economics, forthcoming.

Landes, D. 1998. The Wealth and Poverty of Nations. New York: W. W. Norton.

La Porta, R., F. Lopez-de-Silanes, A. Shleifer, and R. Vishny. 1996. Law and Finance. Journal of Political Economy, 106:4, pp. 1113-1155.

La Porta, R., F. Lopez-de-Silanes, A. Shleifer, and R. Vishny. 1997. Legal Determinants of External Finance. Journal of Finance, 52, pp. 1131-1150. 
La Porta, R., F. Lopez-de-Silanes, A. Shleifer, and R. Vishny. 1999. The Quality of Government. Journal of Law, Economics and Organization, 15: 1, pp. 222-279.

Lerner, J. and A. Schoar. 2005. Does Legal Enforcement Affect Financial Transactions? The Contractual Channel in Private Equity. Quarterly Journal of Economics, 120, pp. 223-246.

Levchenko, A. 2004. Institutional Quality and International Trade. IMF Working Paper.

McLaren, J. 2000. "Globalization" and vertical structure. American Economic Review, 90:5, pp. 1239-54.

Marshall, M. G. and K. Jaggers. 2002. Polity IV Project: Political Regime Characteristics and Transitions, 1800-2002: Dataset Users' Manual. Maryland: University of Maryland.

Nickell, S. 1981. Biases in dynamic Models with Fixed Effects. Econometrica, 49, pp. 1417-1426.

Nordas, H. K. 2004. Determinants of Vertical Specialization. Mimeo.

North, D. C. 1990. Institutions, Institutional Change, and Economic Performance. Cambridge: Cambridge University Press.

Nunn, N. 2005. Relationship-Specificity, Incomplete Contracts, and the Pattern of Trade. University of Toronto.

Putnam, R. 1993. Making Democracy Work: Civic Traditions in Modern Italy. Princeton: Princeton University Press.

Ranjan and Lee. 2004. Contract Enforcement and the Volume of International Trade in Different Types of Goods. Mimeo.

Rauch, J. E. 1999. Networks versus markets in international trade. Journal of International Economics, 48:1, pp. 7-35.

Romalis, J. 2004. Factor Proportions and Structure of Commodity Trade. American Economic Review, 94, pp. 67-97.

Rossi, S. and P. Volpin. 2004. Cross Country Determinants of Mergers and acquisitions. Journal of Financial Economics, 74, pp. 277-304.

Williamson, O. E. 1985. The Economic Institutions of Capitalism. New York: The Free Press.

Yeats, A. 1998. "Just how big is global production sharing?" World Bank Policy Research Working Paper. 